\title{
Determination of Iron and Aluminum Based on the Catalytic Effect on the Reaction of Xylene Cyanol FF with Hydrogen Peroxide and Potassium Periodate
}

\author{
Longfei Cai* and Chunxiu Xu
}

\author{
Department of Chemistry, Hanshan Normal University, Chaozhou, 521041 P. R. China
}

\begin{abstract}
Um método simples, sensível e seletivo para determinação simultânea de traços de ferro e alumínio por espectrofotometria catalítica foi desenvolvido. Esse método baseia-se nos efeitos catalíticos de ferro e alumínio sobre a reação de xileno cianol FF com peróxido de hidrogênio e periodato de potássio. Ferro e alumínio não apresentaram efeitos catalíticos sobre a reação de oxidação do xileno cianol FF em meio contendo apenas peróxido de hidrogênio ou apenas periodato de potássio. Entretanto, foram obtidos efeitos catalíticos significativos de ferro e alumínio quando ambos oxidantes foram usados simultaneamente. Gráficos de calibração linear foram obtidos no intervalo de $3,57 \times 10^{-8}$ a $3,57 \times 10^{-7} \mathrm{~mol} \mathrm{~L}^{-1}$ para Fe e de $1,48 \times 10^{-7}$ a $1,48 \times 10^{-6} \mathrm{~mol} \mathrm{~L}^{-1}$ para Al. Os limites de detecção, baseados no critério de 3 vezes o desvio padrão, foram $1,50 \times 10^{-8} \mathrm{~mol} \mathrm{~L}^{-1}$ para Fe e $6,10 \times 10^{-8} \mathrm{~mol} \mathrm{~L}^{-1}$ para Al. Este método foi aplicado para determinação simultânea de traços de ferro e alumínio em água de torneira, água de lago, de rio e folhas de chá sem etapas de separação e pré-concentração. Os teores de $\mathrm{Fe}$ e $\mathrm{Al}$ em águas de torneira, lago e rio foram $3,13 \times 10^{-7}, 3,21 \times 10^{-7}$ e $2,74 \times 10^{-7} \mathrm{~mol} \mathrm{~L}^{-1}$ para Fe e $1,31 \times 10^{-6}, 9,83 \times 10^{-7}$ e $1,43 \times 10^{-6} \mathrm{~mol} \mathrm{~L}^{-1}$ para $\mathrm{Al}$, respectivamente. As quantidades de $\mathrm{Fe}$ e Al nas folhas de chá foram $3,10 \times 10^{2} \mu \mathrm{g} \mathrm{g}^{-1} \mathrm{Fe} \mathrm{e}$ $7,37 \times 10^{2} \mu \mathrm{g} \mathrm{g}{ }^{-1} \mathrm{Al}$. Estudos complementares são necessários para o entendimento do mecanismo catalítico do ferro e alumínio nesta reação de oxidação inédita.
\end{abstract}

A simple, sensitive and selective method for the simultaneous determination of trace iron and aluminum by catalytic spectrophotometry is presented. This method is based on the catalytic effects of iron and aluminum on the reaction of xylene cyanol FF with hydrogen peroxide and potassium periodate. Both iron and aluminum did not show catalytic effects on the oxidation reaction of xylene cyanol FF in the presence of either hydrogen peroxide or potassium periodate. However, significant catalytic effects of iron and aluminum were obtained when the two oxidants were simultaneously used. Linear calibration graphs were obtained from $3.57 \times 10^{-8}$ to $3.57 \times 10^{-7} \mathrm{~mol} \mathrm{~L}^{-1}$ for Fe and from $1.48 \times 10^{-7}$ to $1.48 \times 10^{-6} \mathrm{~mol} \mathrm{~L}^{-1}$ for Al. The detection limits, based on the 3 -fold standard deviation criterion, were $1.50 \times 10^{-8} \mathrm{~mol} \mathrm{~L}^{-1}$ for Fe and $6.10 \times 10^{-8} \mathrm{~mol} \mathrm{~L}^{-1}$ for Al. This method was applied to the simultaneous determination of trace iron and aluminum in tap water, lake water, river water and tea leaves without separation and preconcentration. Contents of $\mathrm{Fe}$ and $\mathrm{Al}$ in tap water, lake water and river water were $3.13 \times 10^{-7}, 3.21 \times 10^{-7}, 2.74 \times 10^{-7} \mathrm{~mol} \mathrm{~L}^{-1}$ for Fe and $1.31 \times 10^{-6}$, $9.83 \times 10^{-7}, 1.43 \times 10^{-6} \mathrm{~mol} \mathrm{~L}^{-1}$ for $\mathrm{Al}$, respectively. Tea leaves contained $3.10 \times 10^{2} \mu \mathrm{g} \mathrm{g}^{-1} \mathrm{Fe}$ and $7.37 \times 10^{2} \mu \mathrm{g} \mathrm{g}^{-1} \mathrm{Al}$. Further research is required for understanding the catalytic mechanism of iron and aluminum on this novel oxidation reaction.

Keywords: iron, aluminum, xylene cyanol FF, catalytic spectrophotometry

\section{Introduction}

In recent years, there has been a growing interest in understanding the physiological and toxicological role of iron and aluminum in plants, animals and humans. The deficiency of iron is the main cause of anemia, and aluminum is correlated with Alzheimer's disease. ${ }^{1}$

*e-mail: cailf@zju.edu.cn
Consequently, determination of iron and aluminum in environmental samples and foods is important.

Several techniques such as inductively coupled plasma mass spectrometry (ICP-MS), ${ }^{2}$ atomic emission spectrometry (AES), ${ }^{3-6}$ atomic absorption spectrometry $(\mathrm{AAS})^{7-11}$ and chromatography ${ }^{12-14}$ have been reported for the determination of iron and aluminum. However, the relatively high instrumental costs and the needs for preconcentration, chromatographic separation, extraction or coprecipitation 
are the common limitations. In addition, the use of ICP-AES and AAS for the determination of aluminum in water samples may be restricted. Spectrophotometric methods have also been reported for the determination of iron or aluminum based on the complexation reactions between the chelating agents and iron or aluminum ions. ${ }^{15-17}$ However, these spectrophotometric methods mentioned above are usually limited by the low sensitivity, posing difficulties for applications when the contents of iron and aluminum in samples are extremely low. Catalytic kinetics is becoming increasingly promising for the determination of trace or ultra-trace amounts of substances due to its high sensitivity, low costs and simplicity. Various kinetic methods have been reported for the determination of iron and aluminum. ${ }^{18-22}$ To the best of our knowledge, however, few methods for simultaneous determination of aluminum and iron by catalytic kinetics have been reported. Additionally, the kinetic methods reported previously usually suffered from poor selectivity, which limited its application to real samples. In this work, a simple, selective and sensitive method for the simultaneous determination of iron and aluminum by catalytic spectrophotometry is presented, based on the catalytic effects of iron and aluminum on the reaction of xylene cyanol FF by hydrogen peroxide and potassium periodate.

Another novel and creative advance in this work is the use of two combined oxidants. The catalytic spectrophotometric methods for determination of species are usually based on the reactions of a dye by various oxidants..$^{20,23-27}$ However, in those catalytic spectrophotometric methods reported thus far, the oxidation reaction of dye was usually proceeded by one oxidant only. In this work, a catalytic spectrophotometric method based on the oxidation of xylene cyanol FF by double oxidants is presented. Xylene cyanol FF is an acid triphenylmethane dye used for histochemical staining of hemoglobin peroxidase and as a tracking dye for DNA sequencing in electrophoresis. ${ }^{28,29}$ In addition, it had also been used for determination of nitrite by spectrophotometry. ${ }^{30} \mathrm{In}$ this work, both Fe and Al have no catalytic effect when oxidation reaction of Xylene cyanol $\mathrm{FF}$ is proceeded either by hydrogen peroxide or by potassium periodate. However, significant catalytic effects of both $\mathrm{Fe}$ and $\mathrm{Al}$ are obtained when hydrogen peroxide is added together with potassium periodate.

Therefore, an analytical method of catalytic spectrophotometry in the presence of two oxidants is presented in this work. This method was successfully applied to the simultaneous determination of iron and aluminum in environmental water and tea leaves without preconcentration and separation due to its high sensitivity and selectivity. Although oxidation potential of two combined oxidation agents are usually higher than those of the individual oxidation agents, two combined oxidants so far have not been used to enhance the catalytic effect of catalysts on oxidation reaction of dyes. Hence, this work also presents a method to study more and better catalytic spectrophotometric methods by use of two or more oxidants.

\section{Experimental}

\section{Reagents}

All reagents used were of analytical grade. Redistilled water was used throughout.

$\mathrm{A} \mathrm{Fe}^{3+}$ stock standard solution $\left(1.79 \times 10^{-2} \mathrm{~mol} \mathrm{~L}^{-1}\right.$ contained $1.0 \mathrm{~mol} \mathrm{~L}^{-1}$ sulfuric acid) was prepared by dissolving $0.8606 \mathrm{~g} \mathrm{NH}_{4} \mathrm{Fe}\left(\mathrm{SO}_{4}\right)_{2} \cdot 12 \mathrm{H}_{2} \mathrm{O}$ (Huzhou Hushi Chemical Factory, Huzhou, China) in $50 \mathrm{~mL}$ of $2.0 \mathrm{~mol} \mathrm{~L}^{-1}$ $\mathrm{H}_{2} \mathrm{SO}_{4}$ (Nanjing Chemicals Co., Ltd., Nanjing, China) and diluting to $100 \mathrm{~mL}$ with water. Iron(III) working standard solutions were obtained by proper dilution of the stock solution.

$\mathrm{An} \mathrm{Al}^{3+}$ stock standard solution $\left(3.70 \times 10^{-3} \mathrm{~mol} \mathrm{~L}^{-1}\right.$ contained $1.0 \mathrm{~mol} \mathrm{~L}^{-1}$ sulfuric acid) was prepared by dissolving $0.1757 \mathrm{~g} \mathrm{KAl}\left(\mathrm{SO}_{4}\right)_{2} \cdot 12 \mathrm{H}_{2} \mathrm{O}$ (Xingtai Lide Chemicals Co., Ltd., Hebei, China) in $50 \mathrm{~mL}$ of $2.0 \mathrm{~mol} \mathrm{~L}^{-1}$ $\mathrm{H}_{2} \mathrm{SO}_{4}$ and diluting to $100 \mathrm{~mL}$ with water. Aluminum(III) working standard solutions were obtained by proper dilution of the stock solution.

Nitric acid (Suzhou Jingrui Chemicals Co., Ltd., Suzhou, China) solution of $4 \times 10^{-2} \mathrm{~mol} \mathrm{~L}^{-1}$ and $9.90 \mathrm{~mol} \mathrm{~L}^{-1}$ solution of hydrogen peroxide (Tianjin Damao Chemical Factory, Tianjin, China) were also prepared.

Xylene cyanol FF (Sigma, St. Louis, USA) solution of $1.0 \times 10^{-3} \mathrm{~mol} \mathrm{~L}^{-1}$ was prepared by dissolving $0.1346 \mathrm{~g}$ xylene cyanol FF and diluting to $250 \mathrm{~mL}$ with water.

A standard solution of potassium periodate $\left(1.0 \times 10^{-2} \mathrm{~mol} \mathrm{~L}^{-1}\right)$ was prepared by dissolving $2.30 \mathrm{~g} \mathrm{KIO}_{4}$ (Guoyao Group Co., Shanghai, China) and then diluting to $1000 \mathrm{~mL}$ with water.

\section{Apparatus}

A 724 spectrophotometer (Shanghai Optical Instrument Factory, Shanghai, China), wavelength range 400-800 nm with a $10 \mathrm{~mm}$ cell was used for absorbance measurements. A Model 501 thermostatic water bath (Shanghai Experimental Instrument Factory, Shanghai, China) was used to control the reaction temperature. 


\section{Recommended procedure}

Into two $25 \mathrm{~mL}$ stoppered colorimetric tubes, both $0.55 \mathrm{~mL}$ of xylene cyanol FF solution and $0.80 \mathrm{~mL}$ of nitric acid were added. Then a suitable amount of standard or sample solution was added into only one tube. Next, volumes of $0.30 \mathrm{~mL}$ of hydrogen peroxide and $0.30 \mathrm{~mL}$ of potassium periodate were added into both tubes. After the solutions in both tubes were diluted to $25 \mathrm{~mL}$, the contents were heated for 5 or $6 \mathrm{~min}$ at $100{ }^{\circ} \mathrm{C}$ in a thermostated water bath. After the two tubes were cooled down to room temperature in running cold water, the absorbance $(A)$ was measured at $610 \mathrm{~nm}$ with respect to water blank $\left(\mathrm{A}_{0}\right.$ for non-catalytic reaction and $\mathrm{A}$ for catalytic reaction). The difference value $(\Delta \mathrm{A})$ between $\mathrm{A}_{0}$ and $\mathrm{A}$ was calculated.

\section{Sample preparation}

Tap water

Tap water was directly determined by following the recommended procedure.

\section{Lake water and river water}

Samples were collected and filtered through a $0.45 \mu \mathrm{m}$ Millipore membrane filter. Then, several drops of concentrated nitric acid were added and heated for $5 \mathrm{~min}$ at $100{ }^{\circ} \mathrm{C}$ in a thermostated water bath to digest the organics in samples. Afterwards, the $\mathrm{pH}$ was adjusted to 6.5-7.0 with dilute ammonia (Guoyao Group Co., Shanghai, China) and analytes were determined by following the recommended procedure.

\section{Tea leaves}

Tea leaves were ground into fine pieces and were dried in a forced-draft oven for $2 \mathrm{~h}$ at $80^{\circ} \mathrm{C}$. A suitable amount $c a .1 \mathrm{~g}$ was accurately weighed into a small quartz crucible and pretreated as described in reference. ${ }^{31}$ Briefly, the sample was placed in a muffle furnace and heated to $500{ }^{\circ} \mathrm{C}$ for several hours to remove organic compounds. After being cooled to room temperature, a suitable amount of nitric acid solution was added to dissolve Fe and Al from the residue. The solution obtained was quantitatively transferred into a $100 \mathrm{~mL}$ volumetric flask and diluted to the mark with water. Iron and $\mathrm{Al}$ were then determined by following the recommended procedure.

\section{Principle of determination}

The kinetically catalytic reaction was given as the following:

$\mathrm{KIO}_{4}+\mathrm{H}_{2} \mathrm{O}_{2}+\mathrm{Xyl} \mathrm{FF} \stackrel{\mathrm{Fe}, \mathrm{Al}}{\longrightarrow}$ Product
After a given time interval, $t$, and provided that neither reagent was exhausted, the absorbance difference $(\Delta \mathrm{A})$ could be expressed as follows:

$\Delta \mathrm{A}_{\mathrm{t}}=\mathrm{k} \Delta[\mathrm{Xyl} \mathrm{FF}]_{\mathrm{t}}=\mathrm{K}_{1 \mathrm{t}}[\mathrm{Fe}]+\mathrm{K}_{2 \mathrm{t}}[\mathrm{Al}]$

At times $\mathrm{t}_{1}$ and $\mathrm{t}_{2}, \Delta \mathrm{A}$ should be:

$\Delta \mathrm{A}_{\mathrm{t} 1}=\mathrm{K}_{11}[\mathrm{Fe}]+\mathrm{K}_{21}[\mathrm{Al}]$ and $\Delta \mathrm{A}_{\mathrm{t} 2}=\mathrm{K}_{12}[\mathrm{Fe}]+\mathrm{K}_{22}[\mathrm{Al}]$

The conditional constants $\mathrm{K}_{11}, \mathrm{~K}_{21}, \mathrm{~K}_{12}$ and $\mathrm{K}_{22}$ could be determined in reaction systems catalyzed by $\mathrm{Fe}$ or $\mathrm{Al}$ only, with the aid of graphs of $\Delta \mathrm{A}$ versus catalyst concentration at times $t_{1}$ and $t_{2}$. Therefore, the concentrations of catalysts in the samples could be calculated by solving the above equations.

\section{Results and Discussion}

\section{Absorption spectra}

Figure 1 shows that xylene cyanol FF could be oxidized by potassium periodate slightly (curves 1 and 2), but was oxidized relatively well by hydrogen peroxide (curve 5). Iron and $\mathrm{Al}$ did not show any catalytic effects when xylene cyanol FF was oxidized either by potassium periodate or by hydrogen peroxide (curves 2, 3 and 4 and curves 5, 6 and 7). Comparing with the use of one oxidant only, the use of two combined oxidants could enhance the oxidation

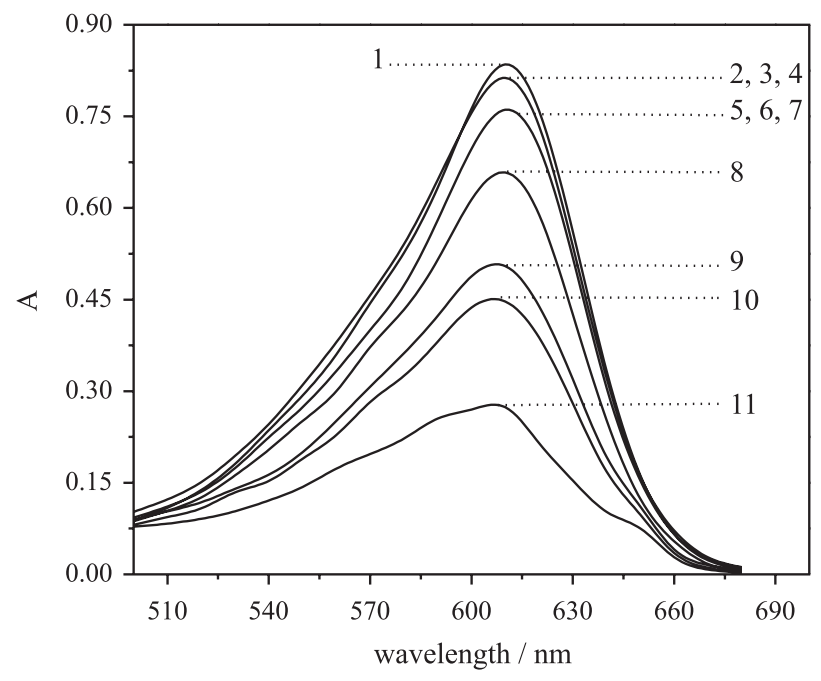

Figure 1. Absorption spectra: 1, Xyl FF $+\mathrm{HNO}_{3} ; 2, \mathrm{Xyl} \mathrm{FF}+\mathrm{HNO}_{3}+$ $\mathrm{KIO}_{4} ; 3, \mathrm{Xyl} \mathrm{FF}+\mathrm{HNO}_{3}+\mathrm{KIO}_{4}+\mathrm{Fe}^{3+} ; 4, \mathrm{Xyl} \mathrm{FF}+\mathrm{HNO}_{3}+\mathrm{KIO}_{4}+\mathrm{Al}^{3+}$; 5 , Xyl FF $+\mathrm{HNO}_{3}+\mathrm{H}_{2} \mathrm{O}_{2} ; 6, \mathrm{Xyl} \mathrm{FF}+\mathrm{HNO}_{3}+\mathrm{H}_{2} \mathrm{O}_{2}+\mathrm{Fe}^{3+} ; 7, \mathrm{Xyl} \mathrm{FF}+$ $\mathrm{HNO}_{3}+\mathrm{H}_{2} \mathrm{O}_{2}+\mathrm{Al}^{3+} ; 8$, Xyl FF $+\mathrm{HNO}_{3}+\mathrm{KIO}_{4}+\mathrm{H}_{2} \mathrm{O}_{2} ; 9$, Xyl FF + $\mathrm{HNO}_{3}+\mathrm{KIO}_{4}+\mathrm{H}_{2} \mathrm{O}_{2}+\mathrm{Al}^{3+} ; 10, \mathrm{Xyl} \mathrm{FF}+\mathrm{HNO}_{3}+\mathrm{KIO}_{4}+\mathrm{H}_{2} \mathrm{O}_{2}+\mathrm{Fe}^{3+}$; $11, \mathrm{Xyl} \mathrm{FF}+\mathrm{HNO}_{3}+\mathrm{KIO}_{4}+\mathrm{H}_{2} \mathrm{O}_{2}+\mathrm{Fe}^{3+}+\mathrm{Al}^{3+} \cdot \mathrm{t}$ (reaction time) $=5 \mathrm{~min}$, $\mathrm{C}_{\mathrm{Fe}}=2.14 \times 10^{-7} \mathrm{~mol} \mathrm{~L}^{-1}, \mathrm{C}_{\mathrm{Al}}=1.19 \times 10^{-6} \mathrm{~mol} \mathrm{~L}^{-1}$. Other conditions were those given in the recommended procedure. 
of xylene cyanol FF (curve 8). The oxidation reaction of xylene cyanol FF by the two combined oxidants could be catalyzed by $\mathrm{Al}$ and $\mathrm{Fe}$ (curves 9 and 10). Higher catalytic effect was noted when the two catalysts were added together (curve 11). All solutions showed a maximum absorbance at $610 \mathrm{~nm}$. Further measurements were therefore made at $610 \mathrm{~nm}$.

\section{Effect of temperature and reaction time}

The experimental results showed that both rates of non-catalyzed and catalyzed reactions increased with temperature, $\Delta A$ increased with temperature and reached the highest value at $100{ }^{\circ} \mathrm{C}$ (Figure 2). The reaction was therefore carried out at $100{ }^{\circ} \mathrm{C}$.

Figure 3 shows that $\Delta \mathrm{A}$ increased with reaction time when the reaction time was lower than $7 \mathrm{~min}$, and $\Delta \mathrm{A}$ increased linearly with reaction time when the reaction

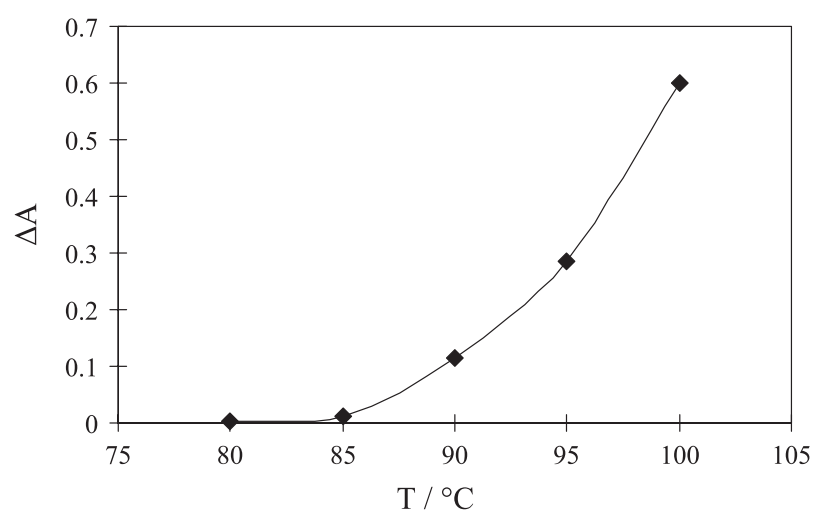

Figure 2. Influence of temperature. $\mathrm{t}=6 \mathrm{~min}, \mathrm{C}_{\mathrm{Fe}}=2.14 \times 10^{-7} \mathrm{~mol} \mathrm{~L}^{-1}$, $\mathrm{C}_{\mathrm{Al}}=1.19 \times 10^{-6} \mathrm{~mol} \mathrm{~L}^{-1}$. Other conditions were those given in the recommended procedure. time was lower than $6 \mathrm{~min}$. Therefore $\Delta \mathrm{A}$ was determined at 5 and $6 \mathrm{~min}$, because the sensitivities were high enough at these times.

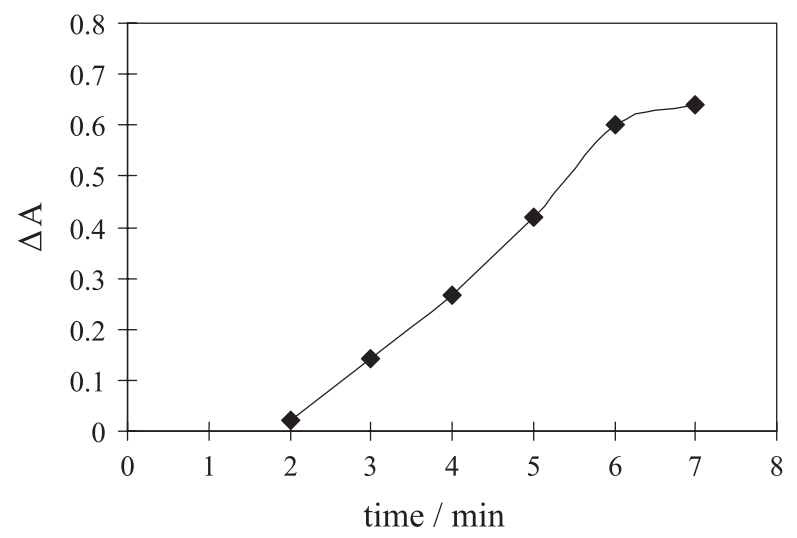

Figure 3. Influence of reaction time. $\mathrm{C}_{\mathrm{Fe}}=2.14 \times 10^{-7} \mathrm{~mol} \mathrm{~L}^{-1}$, $\mathrm{C}_{\mathrm{Al}}=1.19 \times 10^{-6} \mathrm{~mol} \mathrm{~L}^{-1}$. Other conditions were those given in the recommended procedure.

\section{Optimization of the reagent concentrations}

In the preliminary experiments, high $\Delta \mathrm{A}$ values were obtained when xylene cyanol FF, nitric acid, hydrogen peroxide and potassium periodate were added in the following volume ranges: $0.55-0.65,0.60-0.80,0.30-0.50$ and $0.10-0.30 \mathrm{~mL}$, respectively. An orthogonal $\mathrm{L}_{9}(3)^{4}$ test was then designed to establish the optimum conditions based on these preliminary experiments. As shown in Table 1, the orthogonal experiment was carried out with 4 factors and 3 levels, namely volume of xylene FF $(0.55$, 0.60 , and $0.65 \mathrm{~mL})$, volume of nitric acid $(0.60,0.70$, and $0.80 \mathrm{~mL})$, volume of hydrogen peroxide $(0.30,0.40$, and $0.50 \mathrm{~mL})$ and volume of potassium periodate $(0.10,0.20$,

Table 1. Results of orthogonal tests ${ }^{\mathrm{a}}$

\begin{tabular}{lccccc}
\hline No. & $\mathrm{xyl} \mathrm{FF} / \mathrm{mL}$ & $\mathrm{HNO}_{3} / \mathrm{mL}$ & $\mathrm{H}_{2} \mathrm{O}_{2} / \mathrm{mL}$ & $\mathrm{KIO}_{4} / \mathrm{mL}$ & 0.10 \\
\hline 1 & 0.55 & 0.60 & 0.30 & 0.20 & 0.599 \\
2 & 0.55 & 0.70 & 0.40 & 0.30 & 0.505 \\
3 & 0.55 & 0.80 & 0.50 & 0.30 & 0.527 \\
4 & 0.60 & 0.60 & 0.40 & 0.10 & 0.558 \\
5 & 0.60 & 0.70 & 0.50 & 0.20 & 0.304 \\
6 & 0.60 & 0.80 & 0.30 & 0.20 & 0.601 \\
7 & 0.65 & 0.60 & 0.50 & 0.30 & 0.325 \\
8 & 0.65 & 0.70 & 0.30 & 0.10 & 0.584 \\
9 & 0.65 & 0.80 & 0.40 & 0.467 & 0.498 \\
$\mathrm{k}_{1}$ & 0.544 & 0.494 & 0.595 & 0.477 & - \\
$\mathrm{k}_{2}$ & 0.488 & 0.464 & 0.520 & 0.556 & - \\
$\mathrm{k}_{3}$ & 0.469 & 0.542 & 0.385 & 0.089 & - \\
$\mathrm{R}$ & 0.075 & 0.078 & 0.21 & 0.30 & - \\
Optimum & 0.55 & 0.80 & 0.30 & & - \\
\hline
\end{tabular}

aReaction conditions: $\mathrm{t}=6 \mathrm{~min}, \mathrm{C}_{\mathrm{Fe}}=2.14 \times 10^{-7} \mathrm{~mol} \mathrm{~L}^{-1}, \mathrm{C}_{\mathrm{Al}}=1.19 \times 10^{-6} \mathrm{~mol} \mathrm{~L}^{-1}$. Other conditions were those given in the recommended procedure. 
Table 2. Tolerance levels of foreign species in the determination of $2.14 \times 10^{-7} \mathrm{~mol} \mathrm{~L}^{-1} \mathrm{Fe}$ and $1.19 \times 10^{-6} \mathrm{~mol} \mathrm{~L}^{-1} \mathrm{Al}$

\begin{tabular}{llllll}
\hline Ion & Tolerance level / $\left(\mathrm{mol} \mathrm{L}^{-1}\right)$ & Ion & Tolerance level / $\left(\mathrm{mol} \mathrm{L}^{-1}\right)$ & Ion & Tolerance level / (mol L-1) \\
\hline $\mathrm{NH}_{4}^{+}$ & $1.11 \times 10^{-2}$ & $\mathrm{Bi}^{3+}$ & $1.91 \times 10^{-4}$ & $\mathrm{Hg}^{2+}$ & $2.0 \times 10^{-5}$ \\
$\mathrm{Ca}^{2+}$ & $1.0 \times 10^{-2}$ & $\mathrm{~K}^{+}$ & $1.02 \times 10^{-3}$ & $\mathrm{Ag}^{+}$ & $3.7 \times 10^{-5}$ \\
$\mathrm{Mg}^{2+}$ & $8.23 \times 10^{-3}$ & $\mathrm{Co}^{2+}$ & $6.80 \times 10^{-4}$ & $\mathrm{UO}_{2}^{2+}$ & $7.41 \times 10^{-6}$ \\
$\mathrm{Cl}^{-}$ & $5.63 \times 10^{-3}$ & $\mathrm{Ni}^{2+}$ & $6.80 \times 10^{-4}$ & $\mathrm{~V}^{5+}$ & $3.92 \times 10^{-5}$ \\
$\mathrm{SO}_{4}^{2-}$ & $2.08 \times 10^{-3}$ & $\mathrm{As}^{5+}$ & $5.34 \times 10^{-4}$ & $\mathrm{Sn}^{2+}$ & $6.74 \times 10^{-6}$ \\
$\mathrm{NO}_{3}^{-}$ & $3.23 \times 10^{-3}$ & $\mathrm{Mn}^{2+}$ & $1.45 \times 10^{-4}$ & $\mathrm{Re}^{3+}$ & $5.71 \times 10^{-6}$ \\
$\mathrm{Na}^{+}$ & $1.73 \times 10^{-3}$ & $\mathrm{Cu}^{2+}$ & $1.25 \times 10^{-4}$ & $\mathrm{Cr}^{6+}$ & $1.54 \times 10^{-5}$ \\
$\mathrm{Ba}^{2+}$ & $2.91 \times 10^{-4}$ & $\mathrm{~Pb}^{2+}$ & $1.93 \times 10^{-5}$ & $\mathrm{Th}^{4+}$ & $8.62 \times 10^{-8}$ \\
$\mathrm{Cd}^{2+}$ & $3.56 \times 10^{-4}$ & $\mathrm{Zn}^{2+}$ & $6.12 \times 10^{-5}$ & & \\
\hline
\end{tabular}

and $0.30 \mathrm{~mL}$ ). Although the maximum $\Delta \mathrm{A}$ value was 0.601 , the corresponding reaction conditions were not the optimum conditions. To obtain the optimum conditions, the values of $\mathrm{k}$ and $\mathrm{R}$ should be calculated. According to the $R$ values in Table 1, the factors that influenced the $\Delta \mathrm{A}$ value could be listed in a decreasing order as follows: $\mathrm{H}_{2} \mathrm{O}_{2}>\mathrm{KIO}_{4}>\mathrm{HNO}_{3}>$ xyl FF.

The $\mathrm{k}$ values shown in Table 1 indicated that the optimum conditions were $0.55,0.80,0.30$ and $0.30 \mathrm{~mL}$ for xylene cyanol FF, nitric acid, hydrogen peroxide and potassium periodate, respectively. $\Delta \mathrm{A}$ was therefore determined under these optimum conditions for reaching the highest sensitivity.

\section{Interference of foreign species}

The effects of foreign species on the determination of $2.14 \times 10^{-7} \mathrm{~mol} \mathrm{~L}^{-1} \mathrm{Fe}$ and $1.19 \times 10^{-6} \mathrm{~mol} \mathrm{~L}^{-1} \mathrm{Al}$ were studied. Tolerable concentrations of foreign species are shown in Table 2. The tolerance level was defined as the concentration of foreign specie that caused a variation lower than $5 \%$ in $\Delta \mathrm{A}$ value. Table 2 shows that only Th interfered significantly, indicating that the developed method has good selectivity for determining $\mathrm{Fe}$ and Al. Furthermore, the interference of Th will be negligible since concentrations of Th in common samples are much lower than those of $\mathrm{Fe}$ and Al. Hence, this method could be applied to the determination of $\mathrm{Fe}$ and $\mathrm{Al}$ without preconcentration and separation processes.

\section{Calibrations}

Iron and $\mathrm{Al}$ solutions of different concentrations were measured using the reaction system under the optimum conditions mentioned above and $\Delta \mathrm{A}$ was measured at 5 and 6 min. Linear calibration graphs were obtained from $3.57 \times 10^{-8}$ to $3.57 \times 10^{-7} \mathrm{~mol} \mathrm{~L}^{-1}$ for $\mathrm{Fe}$ and from
$1.48 \times 10^{-7}$ to $1.48 \times 10^{-6} \mathrm{~mol} \mathrm{~L}^{-1}$ for $\mathrm{Al}$, and the calibration equations were derived as:

$\Delta \mathrm{A}_{(5 \min )}=7.41 \times 10^{5} \mathrm{C}_{\mathrm{Fe}}+2.20 \times 10^{5} \mathrm{C}_{\mathrm{Al}}-0.010$

$\Delta \mathrm{A}_{(6 \text { min })}=1.20 \times 10^{6} \mathrm{C}_{\mathrm{Fe}}+3.00 \times 10^{5} \mathrm{C}_{\mathrm{Al}}+0.009$

Five standard binary mixtures with different ratios of $\mathrm{C}_{\mathrm{Fe}} / \mathrm{C}_{\mathrm{Al}}$ were employed to perform experiments on recovery. Each one was analyzed 6 times. Results are shown in Table 3. These results also showed that there were no interactions between $\mathrm{Fe}$ and $\mathrm{Al}$.

Table 3. Test of accuracy and precision

\begin{tabular}{lcccccc}
\hline Sample & \multicolumn{2}{c}{ Added $/\left(10^{-7} \mathrm{~mol} \mathrm{~L}^{-1}\right)$} & \multicolumn{2}{c}{ Recovery $/(\%)$} & \multicolumn{2}{c}{ RSD / (\%) } \\
& $\mathrm{Fe}$ & $\mathrm{Al}$ & $\mathrm{Fe}$ & $\mathrm{Al}$ & $\mathrm{Fe}$ & $\mathrm{Al}$ \\
\hline 1 & 2.14 & 1.48 & 99.5 & 103.4 & 1.97 & 3.83 \\
2 & 1.43 & 1.48 & 98.6 & 97.2 & 1.83 & 2.52 \\
3 & 1.43 & 3.00 & 102.9 & 102.3 & 2.33 & 2.67 \\
4 & 2.14 & 11.9 & 101.1 & 98.6 & 2.05 & 2.11 \\
5 & 0.71 & 11.9 & 95.5 & 98.7 & 3.95 & 1.78 \\
\hline
\end{tabular}

The detection limits, based on the $3 \mathrm{~s}^{\mathrm{b}}$ criterion $\left(\mathrm{s}^{\mathrm{b}}\right.$ is the concentration corresponding to the standard deviation obtained from determining blank solution 11 times), were $1.50 \times 10^{-8} \mathrm{~mol} \mathrm{~L}^{-1}$ for Fe and $6.10 \times 10^{-8} \mathrm{~mol} \mathrm{~L}^{-1}$ for Al.

\section{Interaction between the two catalysts}

The experimental results showed that $\Delta \mathrm{A}$ value caused by the mixed catalysts ( $\mathrm{Fe}$ and $\mathrm{Al}$ ) is nearly equal to the total value of $\Delta \mathrm{A}$ caused by $\mathrm{Fe}$ and $\mathrm{Al}$ only, and relative error was lower than $5 \%$. These results indicated that the interactions between $\mathrm{Fe}$ and $\mathrm{Al}$ were negligible within certain concentrations. Therefore, the developed method could be used for the simultaneous determination of $\mathrm{Fe}$ and $\mathrm{Al}$. 
Table 4. Determination of $\mathrm{Fe}$ and $\mathrm{Al}$ in samples

\begin{tabular}{|c|c|c|c|c|c|c|c|c|}
\hline \multirow[t]{2}{*}{ Sample } & \multicolumn{4}{|c|}{$\mathrm{Fe}$} & \multicolumn{4}{|c|}{$\mathrm{Al}$} \\
\hline & Found $/\left(\mathrm{mol} \mathrm{L}^{-1}\right)$ & Added $^{b} / \mu \mathrm{g}$ & Recovery / (\%) & $\mathrm{RSD} /(\%)$ & Found $^{\mathrm{c}} /\left(\mathrm{mol} \mathrm{L}^{-1}\right)$ & Added $^{b} / \mu \mathrm{g}$ & Recovery / (\%) & $\mathrm{RSD} /(\%)$ \\
\hline Tap water & $3.13 \times 10^{-7}$ & 0.2 & 98.5 & 2.05 & $1.31 \times 10^{-6}$ & 0.5 & 96.7 & 1.86 \\
\hline River water & $2.74 \times 10^{-7}$ & 0.2 & 95.6 & 3.99 & $1.43 \times 10^{-6}$ & 0.5 & 98.9 & 2.17 \\
\hline Lake water & $3.21 \times 10^{-7}$ & 0.2 & 97.4 & 1.72 & $9.83 \times 10^{-7}$ & 0.5 & 96.8 & 4.22 \\
\hline Tea leaves & $310.3^{\mathrm{a}}$ & 0.2 & 103.2 & 2.13 & $736.5^{\mathrm{a}}$ & 0.5 & 96.5 & 1.64 \\
\hline
\end{tabular}

${ }^{\mathrm{a}} \mu \mathrm{g} \mathrm{g} \mathrm{g}^{-1}$; bamount of $\mathrm{Fe}$ or $\mathrm{Al}$ added in $25 \mathrm{~mL}$ stoppered colorimetric tubes calculated from the added amount of standard solution before sample pretreatment; ${ }^{\mathrm{c}}$ sample concentration without addition of standard solutions.

\section{Applications}

Owing to its high sensitivity and selectivity, the method here develoepd was applied to the determination of $\mathrm{Fe}$ and $\mathrm{Al}$ in water samples and tea leaves without any prior separation or preconcentration processes. Results are shown in Table 4.

\section{Conclusions}

In conclusion, a catalytic spectrophotometric method for the simultaneous determination of iron and aluminum is presented. This method is simple, sensitive and selective, and it was successfully applied to the simultaneous determination of $\mathrm{Fe}$ and $\mathrm{Al}$ in tap water, lake water, river water and tea leaves without prior separation and preconcentration. This method could also be applied to other samples due to its simplicity, sensitivity and selectivity.

\section{Acknowledgments}

This work was supported by the youth scientific fund of Hanshan Normal University (Grants 413611 and 413615).

\section{References}

1. Fu, K. J.; Cao, G. H.; Xu, Y. G.; He, Q. S.; Human Vital Elements; Chinese Medicine Technology Press: Beijing, 1995.

2. Bianchi, F.; Careri, M.; Maffini, M.; Mangia, A.; Mucchino, C.; Rapid Commun. Mass Spectrom. 2003, 17, 251.

3. Murillo, M.; Benzo, Z.; Marcano, E.; Gomez, C.; Garaboto, A.; Marin, C.; J. Anal. At. Spectrom. 1999, 14, 815.

4. Deng, L. P.; Chin. J. Anal. Lab. 2000, 19, 67. http://www.cnki. com.cn/article/cjfdtotal-fxsy200003022.htm.

5. Tangen, G.; Wickstrøm, T.; Lierhagen, S.; Vogt, R.; Lund, W.; Environ. Sci. Technol. 2002, 36, 5421.

6. Peng, T. Y.; Jiang, Z. C.; Qin, Y. C.; J. Anal. At. Spectrom. 1999, 14, 1049.

7. Canfranc, E. ; Abarca, A. ; Sierra, I.; Marina, M. L.; J. Pharm. Biomed. Anal. 2001, 25, 103.

8. Wang, C.; Hao, Q. L.; Environ. Chem. 1998, 17, 508.
9. Zeiner, M.; Zödl, B.; Steffan, I.; Marktl, W.; Ekmekcioglu, C.; Anal. Bioanal. Chem. 2005, 382, 239.

10. Liu, H. W.; Peng, X. K.; Pan, Z. Q.; Bao, L. S.; Feng, J. L.; Spectrosc. Spect. Anal. 1994, 14, 89.

11. Wróbel, K.; Urbina,E. M.C.; Biol. Trace Elem. Res. 2000, 78, 271.

12. Ruan, Y. P.; Liu, W. Y.; Tian, X. Q.; Zhao, H.; J. Xiamen Univ., Nat. Sci. Ed. 1995, 34, 582.

13. Eyama, T. S.; Uchiumi, A.; Chromatographia 1995, 40, 125.

14. Khuhawar, M. Y.; Lanjwani, S. N.; J. Chromatogr., A 1996, 740, 296.

15. Stalikas, C. D.; Pappas, A. C.; Karayannis, M. I.; Veltsistas, P. G.; Microchim. Acta 2003, 142, 43.

16. Rodrigues, J. L.; de Magalhães, C. S.; Luccas, P. O.; J. Pharm. Biomed. Anal. 2005, 36, 1119.

17. Pascual-Reguera, M. I.; Ortega-Carmona, I.; Molina-Díaz, A.; Talanta 1997, 44, 1793.

18. Kumar, T. N. K.; Revanasiddappa, H. D.; Anal. Bioanal. Chem. 2003, 376, 1126.

19. Hossein, T.; Ali, M.; Talanta 1998, 47, 479.

20. Gong, R. M.; Chen, Q. Y.; Liu, Z. L.; Microchim. Acta 2003, $143,53$.

21. Yu, J. H.; Zhao, G. Q.; Chin. J. Anal. Lab. 2000, 19, 50.

22. Blanco, M.; Coello, J.; Talanta 1993, 40, 261.

23. Du, B.; Yan, T.; Liu, S. Y.; Wang, J.; Wei, Q.; J. Anal. Chem. 2007, 62, 794.

24. Mutaftchiev, K. L.; Chem. Pap. 2006, 60, 279.

25. Fukasawa, T.; Iwatsuki, M.; Kawakubo, S.; Mochizuki, M.; Microchim. Acta 1986, 90, 71.

26. Mohamed, A. A.; Fawy, K. F.; Anal. Sci. 2001, 17, 769.

27. Sikalos, T. S.; Arabatzis, Y. M.; Prodromidis, M. I.; Veltsistas, P. G.; Karayannis, M. I.; Microchim. Acta 2000, 135, 197.

28. Maxam, A. M.; Gilbert, W.; Proc. Natl. Acad. Sci. U. S. A. 1977, 74,560

29. Li, X. J.; Yang, X. P.; Qi, J.; Seeman, N. C.; J. Am. Chem. Soc. 1996, 118, 6131.

30. Dong, C. Z.; Chen, L. G.; Chin. J. Anal. Chem. 1998, $26,858$.

31. Jiang, G. B.; Pretreatment of Environmental Samples; Chinese Chemical Engineering Press: Beijing, 2004.

Submitted: April 9, 2011

Published online: August 23, 2011 